$42: 42$

<原 著 $>$

\title{
インスリンの肝細胞内輸送動態について
}

一光顕扣よび電顕オートラジオグラフィーを用いての観察—

\section{権藤 和久*}

要 旨：インスリンの類洞血中より肝細胞への取り込み, ならびに肝細胞内輸送動態を観察す るために, ${ }^{125} \mathrm{I}$ ろンスリンを用い光顕・電顕オートラジオグラフィーにより観察した. ラット腸 間膜静脈より投与されたインスリンは, 中心静脈周囲肝細胞に比し, 門脈周囲肝細胞に有意に 多く取り込まれた.インスリンは類洞血中から endocytosisにより肝細胞内に取り込まれ， coated vesicle に包まれ，肝細胞内を毛細胆管側へと輸送されて胆汁中へ排泄されるものと， RER, 核膜へ輸送されるものとが観察された。

コルヒチン投与により肝細胞原形質内の microtubules を障害すると,インスリンの肝細胞へ の取り込みには影響はみられないが，その肝細胞内輸送は抑制され，インスリンの肝細胞内輸 送に microtubules が重要な役割をなしていると考えられた。

索引用語： 光顕・電影オートラジオクラフィー インスリン（肝細胞内輸送）

胆计分泌 microtubules

\section{緒 言}

インスリンは，肝細胞での種々の物質代謝に重要な ホルモンであるが, 近年, 肝再生を促進するhepatotrophic factor として, 臨床的にもグルカゴンイ ンスリン療法に用いられている。しかし，インスリン の肝細胞での動態には不明な点も多く，また，肝細胞 内小器官との関連も明確ではない,一方, 近年, in vivo において, 電顕オートラジオグラフィーを用い, $\operatorname{IgA}{ }^{11}$, glycoprotein, polypeptide hormone, VLDL 21 などの 種々の物質の肝細胞への取り込み，細胞内輸送動態を 観察した報告がみられる。そこで今回, ${ }^{125} \mathrm{I}$-インスリン の肝細胞内での輸送動態を解明すべく，光顕ならびに 電顕オートラシオグラフィーを用いて観察した。また， インスリンの肝細胞内輸送が， vesicular transport を 介したすのであると考えられているため, vesicular transport に関与する microtubules 障害するコル ヒチン投与による，インスリンの肝細胞内動態への影 響についても観察し，さらに，胆汁中 ${ }^{125}$ I放射活性の推 移についても検討を加えた。

対象およU方法

I）光顥および電顯オートラジオグラフィー

- 久留米大学第 2 内科

〈受付日60年 4 月 1 日 $>$ 体重150〜200gのウィスター系雄性ラットを用い， Pentobarbital $0.1 \mathrm{cc} / 100 \mathrm{~g}$ 体重の腹腔内麻酔後, 開腹 した。 ${ }^{125} \mathrm{I}$ インンスリン (New England Nuclear 社)を, 体重 $100 \mathrm{~g}$ あたり $35 \mu \mathrm{Ci}$ 腸間膜静脈枝より注入した。 1 分後, 10 分後, 20 分後に, 門脈より Hanks 溶液 $(\mathrm{pH}$ 7.4) で $5 \mathrm{~m} l / \mathrm{min}$ の速さで約 15 秒間灌流し, 次いで, $4{ }^{\circ} \mathrm{C} の 2.5 \%$ glutaraldehyde $と 0.8 \%$ paraformaldehyde の混合液で約 2 分間, 肝を灌流固定した。灌流後, 肝組織を約 $1 \mathrm{~mm}^{3}$ のブロックとし，同様の固定液でさ らに 2 時間浸漬固定した。組織を $0.2 \mathrm{M} \mathrm{Na}$ bicarbonate buffer で約12時間洗浄し，一部を光顕オートラ ジオグラフィーのためにパラフィン包埋し残りを $1 \%$ オスミウム酸で後固定, アセトンで脱水後, Epon 812 で包埋した. バラフィン包埋した組織を薄切し，スラ イト上に載せ,生乳剂 Sakura NR-M ping 法で塗布した. $2 \sim 4$ 週間， $4{ }^{\circ} \mathrm{C} て ゙$ 遮光した箱中 で露出させ, コニドールXで, $16^{\circ} \mathrm{C} ４$ 分間現像し， Methylgreenで染色を30分行ない，光顕的観察を行 なった. Epon 812で包埋した組織は，超薄切後、スラ イド上に載せ， $2.5 \%$ 酢酸ウラン, Reynolds 鉛溶液で 電子染色を行なった. その後, 切片上に生乳剂 Sakura $\mathrm{NR} \cdot \mathrm{H}_{2}$ 学希釈し Dipping 法で㳊布した. 4 - 8 週間露 出させ，現像し，切片をメッシュに載せた後，電子顕 微鏡で観察した。 


\section{II) 組織化学}

Glycoprotein であり，肝細胞に取り込まれ，細胞内 を vesicular transportされるHorseradish peroxidase (HRP) を125I-インスリンと同時に投与し，イン スリンと vesicle との関連を観察した。 HRPを10mg/ $100 \mathrm{~g}$ 体重, ${ }^{125} \mathrm{I}$-インスリンと同時に腸間膜静脈枝より 注入し, 上述と同様の方法で灌流固定, $1 \mathrm{~mm}^{3}$ のプロッ クを作製した，ブロックを vibratome で $40 \mu \mathrm{m}$ に薄切 し, DAB 溶液で30分間浸漬, さらに0.05\% $\mathrm{H}_{2} \mathrm{O}_{2}$-DAB 容夜で 30 分間反応させた後, 電顕オートラジオグラ フィ一用に試料を作製した。

\section{III) 胆汁中 ${ }^{125}$ I 放射活性}

ウィスター系雄性ラット，体重150〜200gを， Pentobarbital 麻酔後, 開腹し, 総胆管にカテーテルを 插入した。次いで, 腸間膜静脈枝より ${ }^{125} \mathrm{I}$-インスリンを $17 \mu \mathrm{Ci} / 100 \mathrm{~g}$ 体重, 注入し，注入後， 10 分間隔で 120 分 間胆计を採取して胆汁中の ${ }^{125}$ I 放射活性をオートウェ

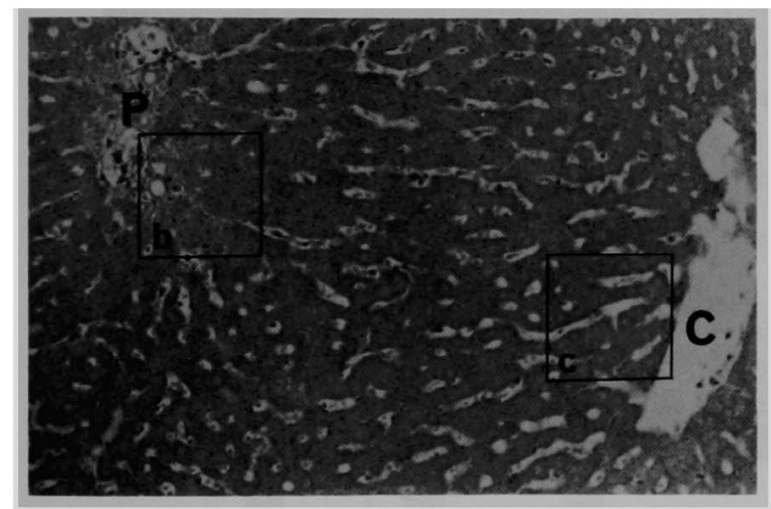

a)

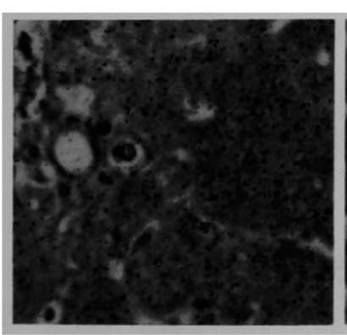

b) periportal

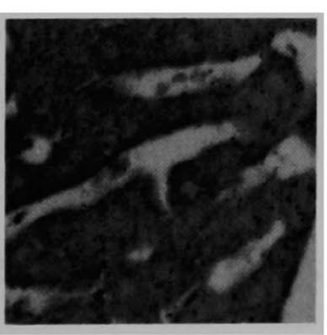

c) perivenous
Fig. 1 Light microscopic autoradiograph of the control rat liver at $10 \mathrm{~min}$ after the injection of ${ }^{125}$ I-insulin into the mesenteric vein. A lobular gradient of grains is apparent from the periportal to the perivenous region.

$\mathrm{P}$; portal vein, $\mathrm{C}$; central vein $(\mathrm{a} ; \times 100 . \mathrm{b}, \mathrm{c} ; \mathrm{X}$ 200).
ルガンマーシステム（アロカJDC751）で測定した。

IV) コルヒチン投与

ウィスター系雄性ラット，体重150２00gにコルヒ チン (colchicine, Nakarai Chemicals. LTD.) 0.05 $\mathrm{mg} / 100 \mathrm{~g}$ 体重, 腹腔内注射し 4 時間後に I)II)III) と同 様の実験を行なった。

\section{結 果}

1）光顥オートラジオグラフィー

光顕オートラジオグラフィーによる観察では, ${ }^{125} \mathrm{I}-$ インスリンの grain は, 黒い粒子として観察されるが, コントロールラットで， ${ }^{125} \mathrm{I}-$ インスリン投与10分後で その肝細胞への取り込みの分布を検討した (Fig. 1). 旰小葉を periportal, mid-zonal, perivenous $の 3$ 部に 分け、それぞれ肝細胞100個にみられる grain 数を算出 すると, 肝細胞 1 個あたりの grain 数は, periportal； 25.6個, mid-zonal; 20.3個, perivenous; 14.8 個と中 心静脈周囲肝細胞に比し, 門脈周囲肝細胞に有意に多 く(p<0.001) みられた (Fig. 2).

コントロールラットの ${ }^{125}$ I-インスリン投与 1 分後の 肝では, grainは, 類洞側の肝細胞質に多数集まってお ク (Fig. 3-a)，これはコルヒチン投与ラットです同様 であった(Fig. 3-b). 10分後, コントロールラットで は grain は肝細胞質深部にみられ(Fig. 4-a)一方, コ ルヒチン投与ラットでは依然として, 類洞側に多くみ

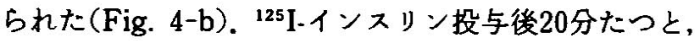

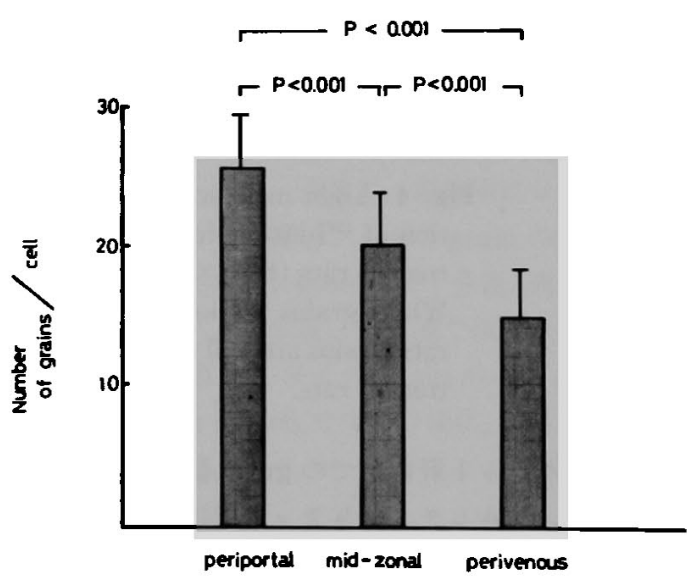

Fig. 2 The number of autoradiographic grains over rat hepatocytes in the periportal, mid-zonal, and perivenous regions.

The hepatocyte of the periportal region contains significant more grains than that of the midzonal and perivenous region. $p<0.001$, mean + $\mathrm{SD}$. 


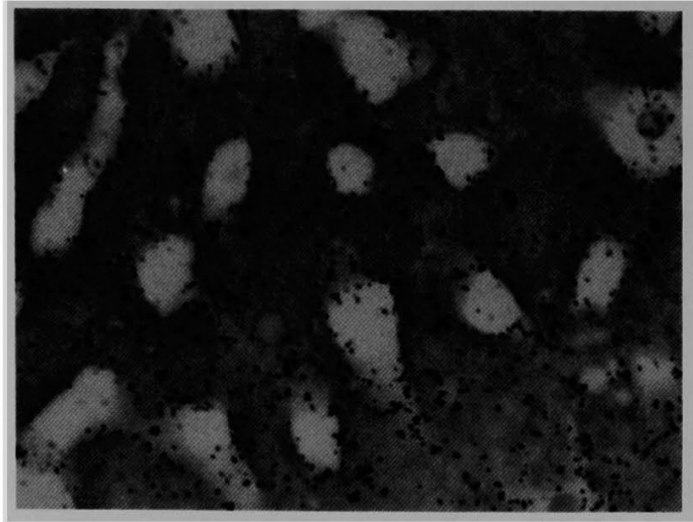

a

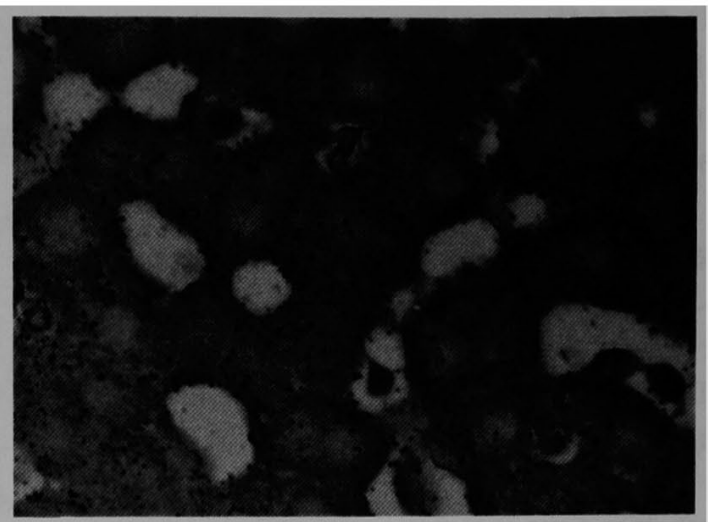

b

Fig. 3 Light microscopic autoradiographs of the liver at $1 \mathrm{~min}$ after the injection of ${ }^{125} \mathrm{I}$-insulin in control rats (a) and in rats pretreated with colchicine (b). ( $X$ 400).

Grains of ${ }^{125}$ I-insulin are observed at the cell periphery of hepatocytes along sinusoids.

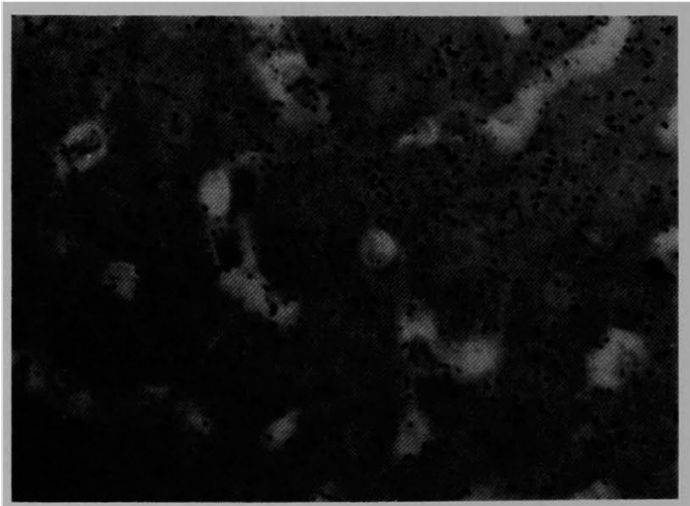

a

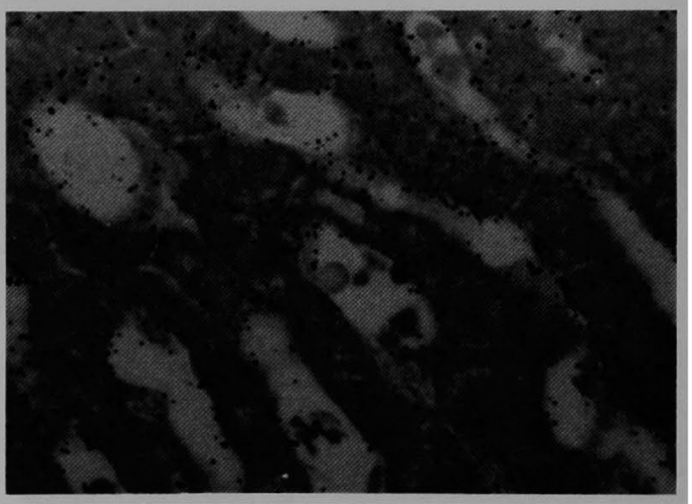

b

Fig. 4 Light microscopic autoradiographs of the liver at $10 \mathrm{~min}$ after the injection of ${ }^{125} \mathrm{I}$-insulin into the mesenteric vein of control rats (a) and colchicinetreated rats (b). $(\times 400)$.

While, grains are located predominantly in the hepatocyte interior in control rats, grains are still observed at the cell periphery along sinusoids in colchicinetreated rats.

コントロールラット肝細胞での grain 数は減少してい るのに対し、コルヒチン投与ラットでは, 一部はまだ 類洞側肝細胞原形質に残存していた（Fig. 5-a, b). mid-zonal の肝細胞100個にみられる grain 数の細 胞 1 個あたりの平均値を Fig. 6に示す. インスリン投 与 1 分後では, コントロールラットとコルヒチン投与 ラットで有意差はみられないが，10分後，20分後にお いて,コルヒチン投与ラット肝細胞に有意に多くの grain が残存していた $(\mathrm{p}<0.001)$.
2）電䫓オートラジオグラフィー

電䫓オートラジオグラフィーによる観察では, ${ }^{125} \mathrm{I}$ インスリン投与 1 分後, grain は, 肝細胞の sinusoidal plasma membrane 上にみられ，その多くは, coated pit と関連していた(Fig. 7-a). 10分後には, 類洞側の 原形質内に endocytic vesicleとして観察され（Fig. 7-b)，また，HRPを含も vesicle 内にみられた（Fig. 8). ${ }^{125} \mathrm{I}$ イインスリンの grain は, 毛細胆管近くへと輸送 され(Fig. 9-a)，すでに毛細胆管へ排泄されている像 


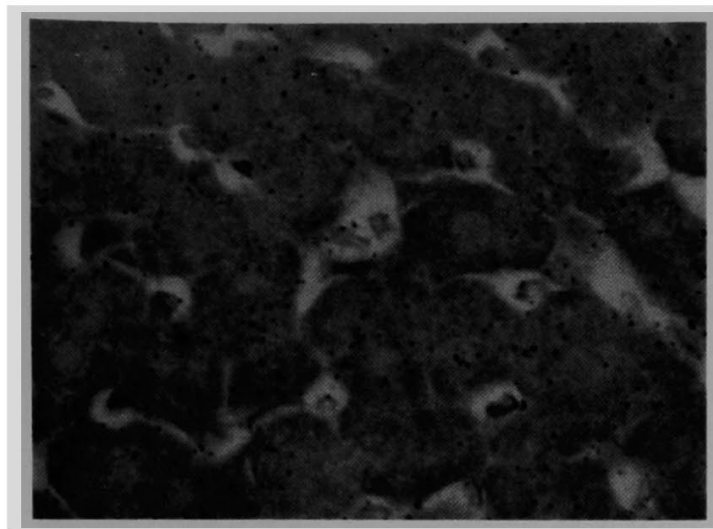

a

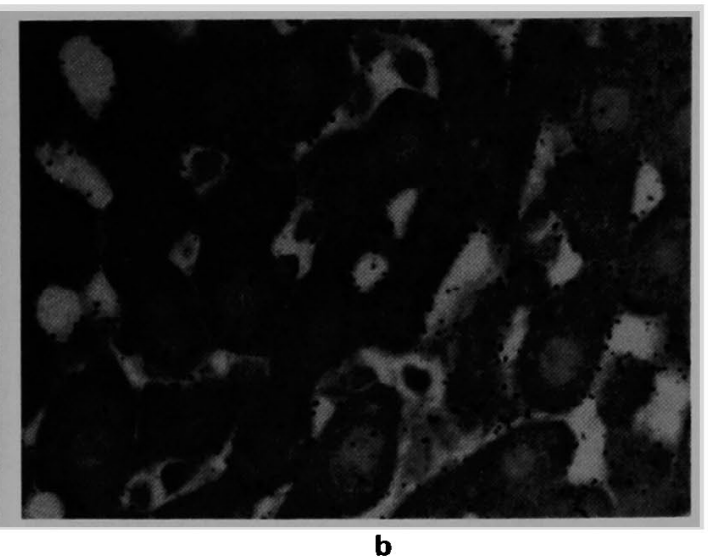

b

Fig. 5 Light microsopic autoradiographs of the liver at $20 \mathrm{~min}$ after the injection of ${ }^{125} \mathrm{I}$-insulin into the mesenteric vein of control rats (a) and colchicine-treated rats (b). $(\times 400)$.

Although significantly fewer grains are presented over the hepatocyte in control rats, more grains are still located at the cell periphery in colchicinetreated rats.

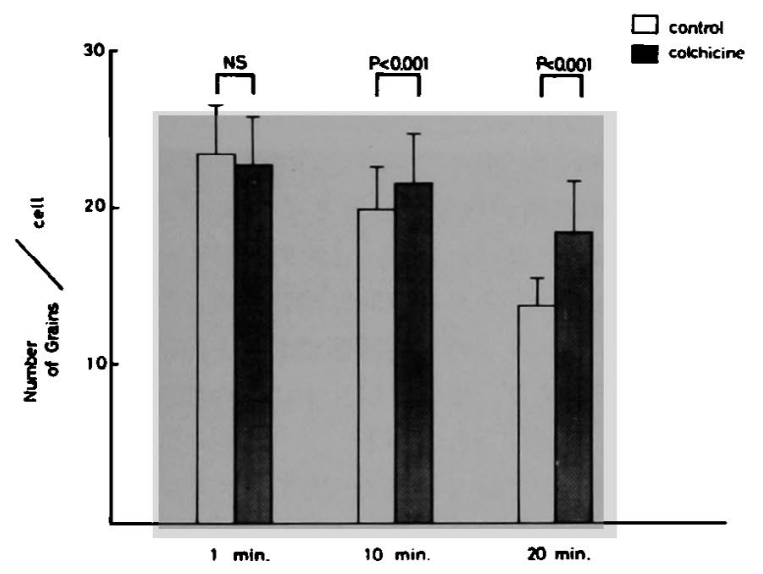

Fig. 6 The number of grains over the rat hepatocyte in the mid-zonal region at $1 \mathrm{~min}, 10 \mathrm{~min}$, and $20 \mathrm{~min}$ after the injection of ${ }^{125} \mathrm{I}$-insulin. Not significant compared to control and colchicinetreated rats at $1 \mathrm{~min}$.

Difference between control and colchicine-treated rats at $10 \mathrm{~min}$ and $20 \mathrm{~min}$ is significant $(p<$ $0.001)$ mean + SD.

る観察された（Fig. 9-b）。また一部の grain は RER, 核膜に観察された（Fig. 10-a,b）.

一方，コルヒチン投与ラットでは，肝細胞原形質内

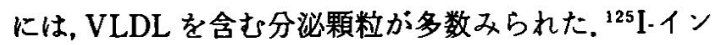
スリンのgrainは20分後でも類洞側 plasma membrane 近傍に多くみられ, 毛細胆管近傍には少数の grain しか観察されなかった。 また, 類洞側の肝細胞原 形質には, lysosomeに取り込まれた grain b多く観察 された（Fig. 11）。

肝細胞原形質を，類洞側より $2 \mu \mathrm{m}$ 以内（subsinusoidal region), 毛細胆管より $2 \mu \mathrm{m}$ 以内（pericanalicular region), およびその中間部 (mid-region) の 3 部に分け, 肝細胞内にみられる grainの,それぞれの部 における割合を各時間において算出した(Fig. 12). コ ントロールラットでは, 1 分後, grain $66 \%$ かi subsinusoidal region にみられるが，10分，20分と，時間 とともに mid-region, pericanalicular region一と移 行していった。 また，同様に，部位別にコントロール ラットとコルヒチン投与ラットで grain の数を比較す ると, subsinusoidal region では 1 分後, 両群間に有意 差は認めないが，10分後，20分後では，コルヒチン投 与ラットで同部位に多くの grainがみられた。一方 pericanalicular region では20分後に,コルヒチン投与 ラットに比し，コントロールラットに有意に多くの grain が認められた。

\section{3）胆汁中 ${ }^{125} I$ 放射活性}

胆汁中に排泄される放射活性の peak は, ${ }^{125} \mathrm{I}$-インス リン投与30分後にみられ，一方，コルヒチン投与ラッ トでは，胆计中の ${ }^{125} \mathrm{I}$ 放射活性の peak は,コントロー ルラットの約54\%減少していた（Fig. 13).

\section{考案}

1）コントロールラット肝でのインスリン動態 


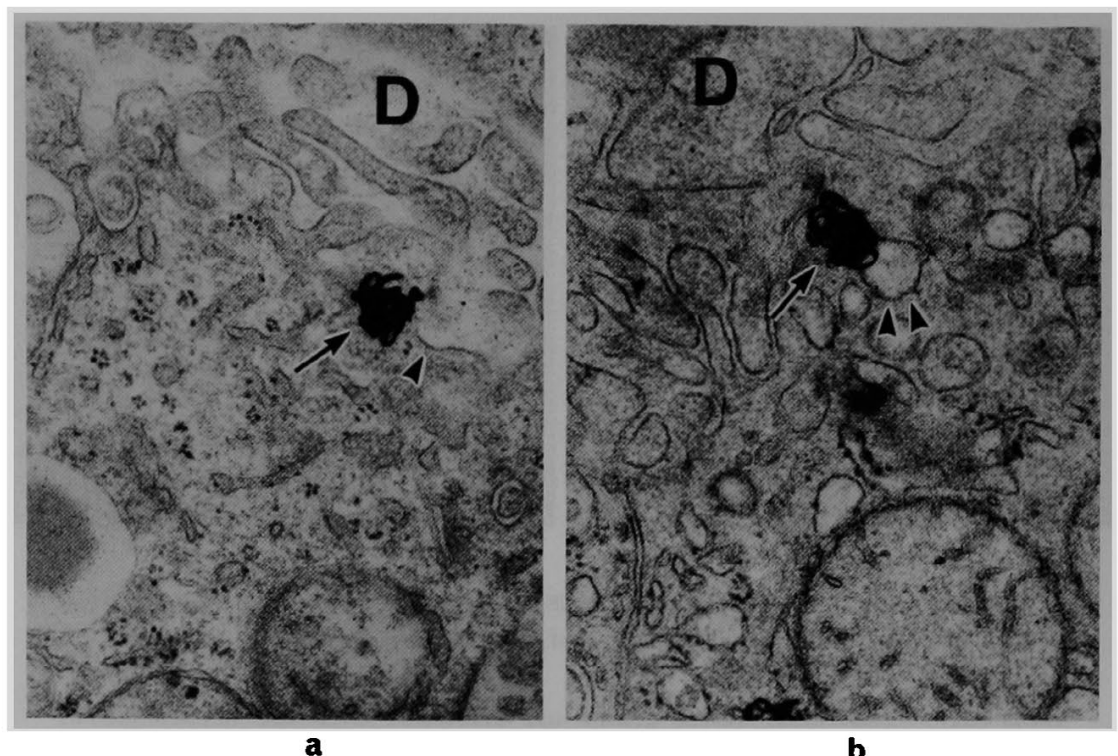

Fig. 7 Electron microscopic autoradiographs of the liver from control rats at $1 \mathrm{~min}$ (a) and $10 \mathrm{~min}$ (b) after ${ }^{125} \mathrm{I}$-insulin injection. Grains (arrow) over the sinusoidal surface of the hepatocyte are associated with coated pits (arrowhead). $10 \mathrm{~min}$ after the injection, grains (arrow) are associated with coated vesicle (double arrowheads). $D$; space of Disse $(a ; \times 40,000, b ; \times 45,600)$.

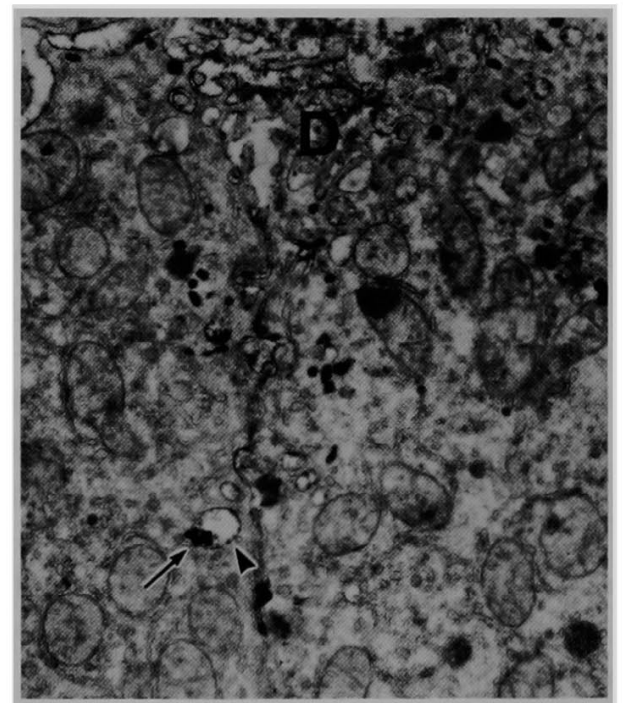

Fig. 8 Electron microscopic histochemistry of HRP and autoradiography of ${ }^{125} \mathrm{I}$-insulin of the liver from control rats at $10 \mathrm{~min}$ after the simultaneous injection of ${ }^{125} \mathrm{I}$-insulin and HRP. Grains (arrow) are associated with vesicles containing HRP (arrowhead). D ; space of Disse $(\times 15,200)$.
苹蔵の $\beta$ 細胞から分泌されるインスリンは門脈血 により肝蔵へと運ばれるが, この時, 旰を一度通過す ると (one-pass)，その40〜50\%が肝に取り込まれる。 肝蔵は，インスリンの標的喴器であると同時に, その 代謝の場でもあり，また，胆汁中にその代謝産物が排 泄されることが知られている。

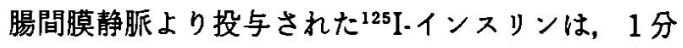
後にはすでに肝細胞に取り込まれ，光顕オートラジオ グラフィーによる観察では, 肝細胞内に黒い粒子 (grain)として観察される. ${ }^{125} \mathrm{I}$-インスリン投与10分後 の grain 数は, 中心静脈周囲肝細胞 (平均14.8個)に比 し，門脈周团肝細胞（平均25.6個）に有意に多くみら れる。このことは, 従来より両肝細胞間には, 構造, 酵素活性に差異がみられるといら肝細胞の小葉内 heterogeneity ${ }^{3,4)}$ のつのあらわれかもしれない. 一 方, ある種の物質では, 高濃度にして投与したり, 逆 行性灌流肝では，その肝小葉内での取り込みにおける heterogeneity が認められなくなったり，また逆の小 葉内 gradient が観察されるといら報告もある5).しか し, 少なくとも門脈周囲肝細胞の類洞血中のほうに高 い濃度のインスリンがみられる生理的条件下では、今 回の結果のように, インスリンは中心静脈周囲肝細胞 


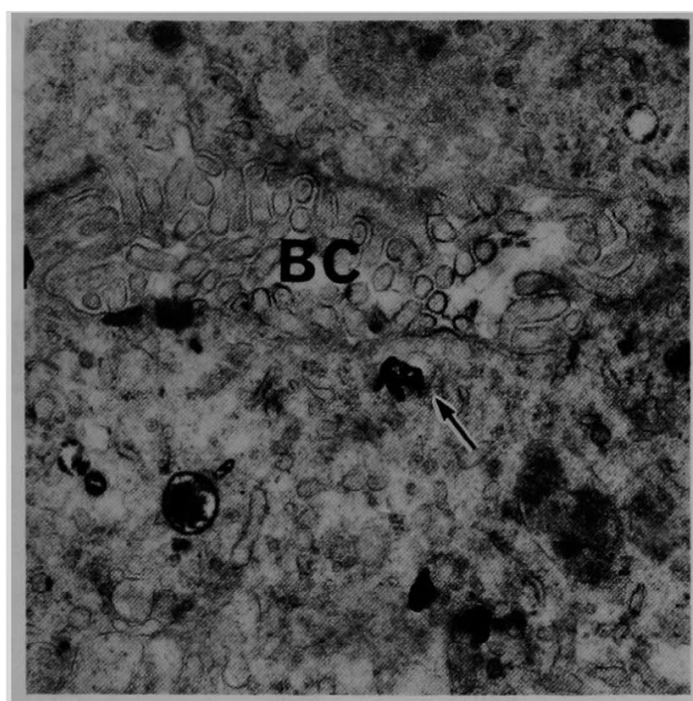

a

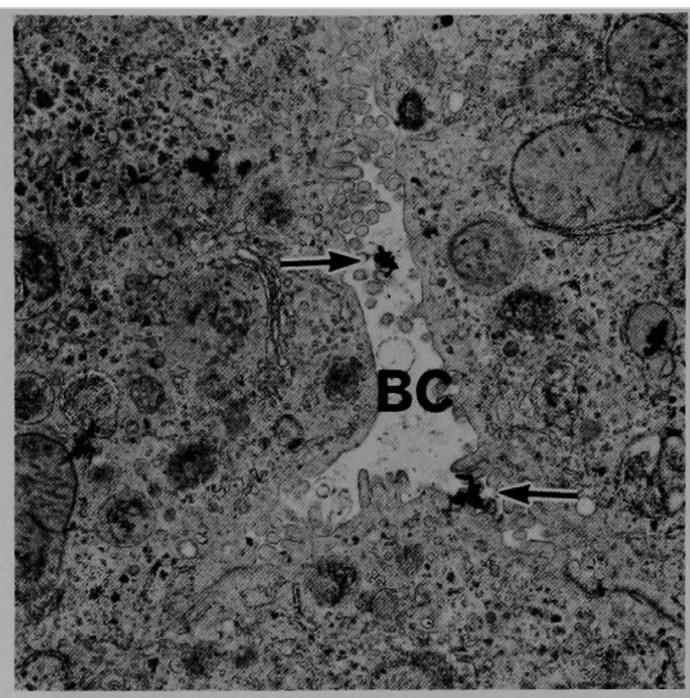

b

Fig. 9 Electron microscopic autoradiographs at $10 \mathrm{~min}$ after the injection of ${ }^{125}$ I.insulin. Grains (arrows) are seen in the vicinity of the bile canaliculus (a), and in the lumen of the bile canaliculus (b). BC; bile canaliculi $(\mathrm{a} ; \times 21,500$, b ; $\times 13,600$ ).

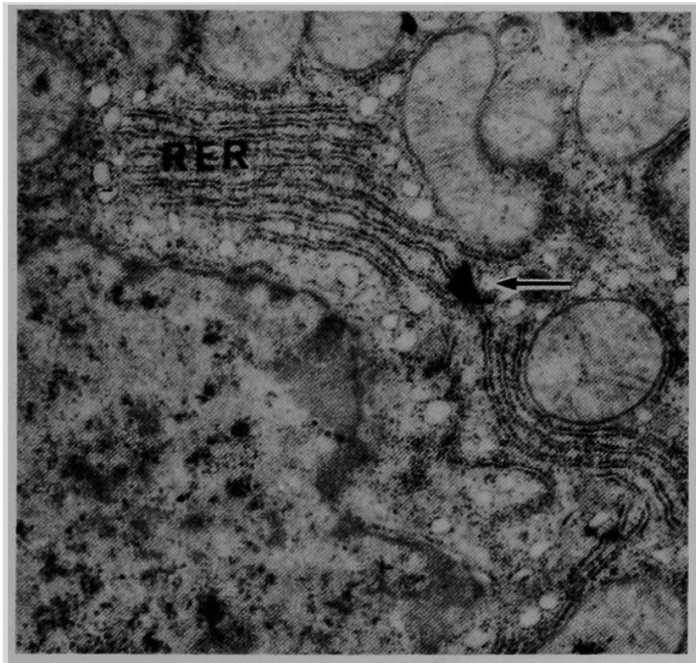

a

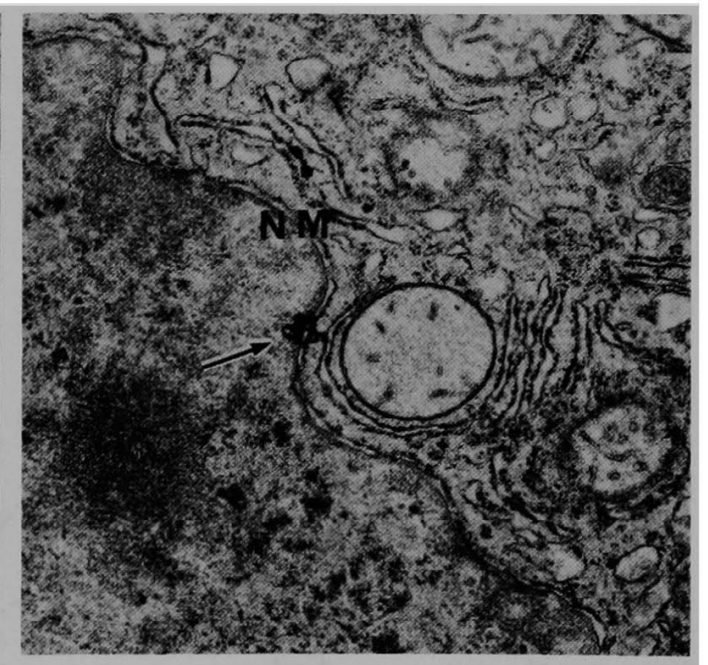

b

Fig. 10 Grains (arrow) are observed associated with the rough endoplasmic reticulum (a) and nuclear membrane (b). RER; rough endoplasmic reticulum, $\mathrm{NM}$; nuclear membrane $(\mathrm{a} ; \times 15,000, \mathrm{~b} ; \times 25,700)$.

に比し，門脈周囲肝細胞により多く取り込まれるとい ら，小葉内での取り込みの差があることが考えられた。 次に, grainの分布の経時的変化では, ${ }^{125} \mathrm{I}$ ーインスリ ン投与 1 分後に類洞側の肝細胞原形質に多数認められ
た grain は, 10分後には, 肝細胞質深部に多くみられる よらになり,さらに時間を経ると, 肝細胞内にみられ る grain 数む減少してくる (Fig. 6).

電顕オートラジオタラフィーによる観察でも， ${ }^{125}$ I- 


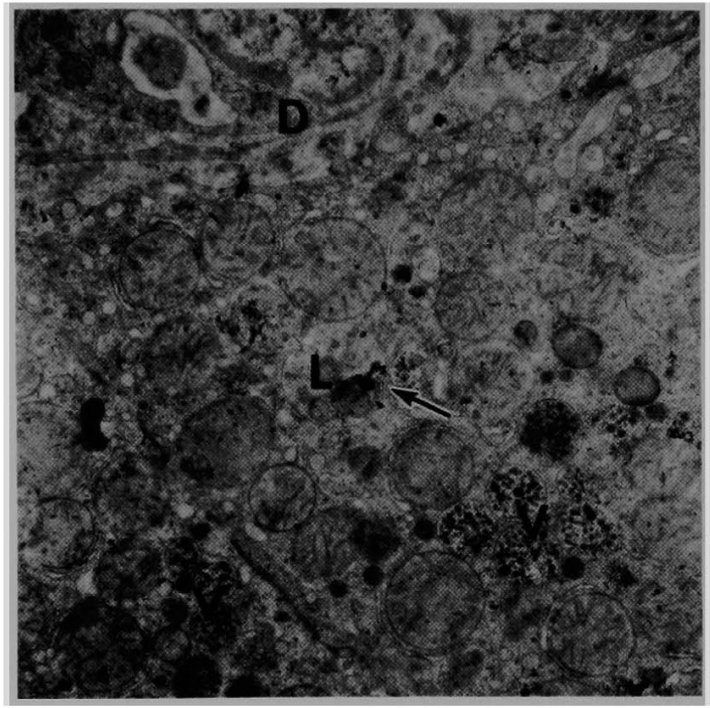

Fig. 11 Electron microscopic autoradiograph of the liver from colchicine-treated rats at $20 \mathrm{~min}$ after the injection of ${ }^{125} \mathrm{I}$-insulin.

Grains (arrow) are in secondary lysosomes (L) near the sinusoidal plasma membrane of the hepatocyte. D; space of Disse, L; lysosome, V ; VLDL containing vesicles $(\times 11,600)$.
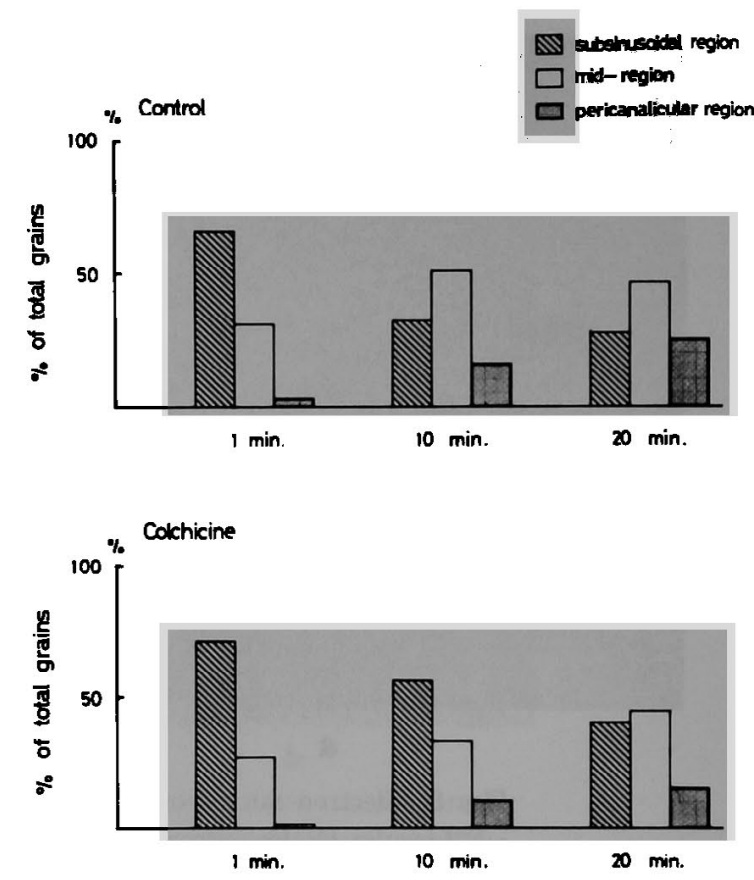

Fig. 12 The distribution of grains in hepatocytes in electron microscopic autoradiographs at lmin, $10 \mathrm{~min}$, and $20 \mathrm{~min}$ after the injection of ${ }^{125} \mathrm{I}$-insulin.

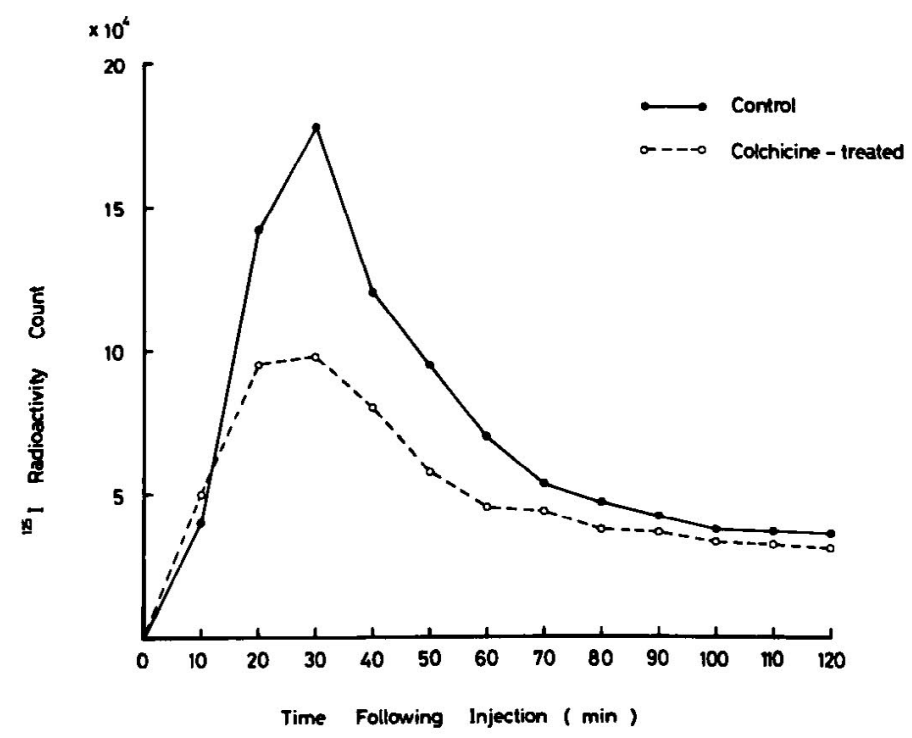

Fig. 13 The appearance of ${ }^{125}$ I radioactivity in bile is shown. The peak secretion of ${ }^{125} \mathrm{I}$ occured at $30 \mathrm{~min}$ after ${ }^{125} \mathrm{I}$-insulin injection in both control and colchicinetreated rats.

The maximum activity of ${ }^{125}$ I secretion in colchicine-treated rats is decreased to 54 percent of control rats. 
インスリン投与 1 分後には, grain $66 \%$ が subsinusoidal regionにみられるが，時間の経過とともに pericanalicular region に増加してくる (Fig. 12)。こ のことは，インスリンは，類洞血中より肝細胞に取り 込まれて細胞内を輸送され，代謝を5け，また一部は 毛細胆管より排泄されたことを推察させる (Fig. 13). インスリンの肝細胞での取り込みは receptormediated endocytosisであることが知られている6). insulin receptor $は$, 分子量約95.000の $\beta$-subunit 2 個 之, 分子量約13,500の $\alpha$-subunit 2 個の glycoprotein からなっていて、肝細胞の表面に均一に分布している。 インスリンが receptor に結合すると, insulin-receptor complex は, coated pit region に集まる. coated pit は clathrin といら分子量 180,000 の polypeptide が 結合して電顕的には格子状の構造物として観察され る. coated pitに集まったインスリンは, endocytosis により細胞内に取り込まれ coated vesicle 内に認めら れるよらになるが，本研究でもまず， coated pit (Fig. 7-a）へ集まったインスリンは, coated vesicle (Fig. 7-b）に取り込まれる。肝細胞内を vesicleに包まれて 輸送される、いわゆる vesicular transport されるもの として知られている $\mathrm{HRP}^{7,8)}$ と $^{125} \mathrm{I}$ イインスリンを同時 に投与すると，インスリンの grain は，HRPを含む vesicle 内に見られ(Fig. 8)，インスリンもまた，vesicleに包まれて輸送される vesicular transportである ことが確かめられた. インスリンを含む vesicleは，や がて毛細胆管側へと輸送されるが (Fig. 9-a,b)，イン スリンは，この vesicle 内で膜にあるインスリン分解 醅素 insulinase により代謝され，胆汁中へ排泄される と考えられている。また，一部のインスリンは，肝細 胞内で RER，核膜に分布して観察された（Fig. 10-a， b).インスリンと肝細胞内小器官との関連で, Goldfine ら9は，インスリンは multivesicular body, ER，核膜 にみられたと報告している。一方，Bergeronら ${ }^{10)}$ lysosome like vacuole にみられ，ERにはなかったと しまた，Carpentier ら"1)は，毛細胆管近くの lysosome に取り込まれると考えている。本研究でもみ られるような，RER，核膜との関連については，インス リンが細胞表面にある insulin receptor の合成の一過 性として細胞内に存在するすのに結合したにすぎず， ホルモン作用における意味はない，上する意見 ${ }^{122}$ ンスリンのホルモン作用としての第一歩は $\beta$-subunit の phosphorylation ${ }^{13)}$ で，ホルモン作用の為に internalization される意義はないとする見解すある。しか
し，Goldfine ${ }^{(4)}$ は，細胞内にすインスリンに対する receptorがあり，細胞表面の receptor とは違った特徽 を備えていると報告しており，RER，核膜と直接結合 し，そこでインスリンとしてのホルモン作用を発揮す る可能性も十分推察された，今回の研究で観察された RER，核膜に輸送されたインスリンか，その後再び vesicular transport で毛細胆管側へ運ばれるか，もし くは， lysosome に取り込まれて代謝されるかなどにつ いては，今後さらに詳細な検討が必要であると考えら れた.

2）コルヒチン投与ラット肝でのインスリン動㮩

肝細胞原形質内に存在する microtubules は, 細胞形 態の保持, lysosomeなどの細胞内小器官の細胞内移 動,物質の細胞内輸送に関与しているといわれており， vesicular transport の際にはその移送のガイドワイ ヤ一的役割をなすと考光られている。コルヒチンは， microtubules の構成蛋白である tubulin 蛋白と特異的 に結合し，その重合阻止や脱重合を起こす，肝細胞に 取り込まれ，vesicular transportにより肝細胞内を輸 送される HRPを用いた向坂らの研究 ${ }^{15,16)}$ では、コル ヒチン投与により，その細胞内輸送が障害され，胆汁 中排泄が低下するため，肝細胞内の vesicular transport を介した細胞内輸送には microtubules が重要な 役割を果たしているとしている。

今回の実験では，コルヒチンは，インスリンの肝細 胞への取り込みにはあまり影䬸を与去なかった（Fig. 6).しかし，経時的に観察すると，インスリンの grain は，時間を経ても，コントロールラットより有意に多 く肝細胞内に残存しており (Fig. 6)，コルヒチンは, インスリンの代謝・排泄過程に遅延をもたらすことが 推察された，電顕オートラジオグラフィーによる観察 では, ${ }^{125}$ I-インスリン投与 1 分後, 類洞側の細胞質にみ られる grainの占める割合はコントロールラットと有 意差はみられない，10分後，20分後ではコントロール ラットにおいて, grain は毛細胆管周囲に増加してく るが、コルヒチン投与ラットでは，類洞側の細胞質に 依然として有意に多くの grainが残っていた。また，毛 細胆管周囲への集積も有意に少なかった，以上のこと より、コルヒチンは, インスリンの肝細胞内輸送を障 害することが考えられた。 また，コルヒチン投与ラッ

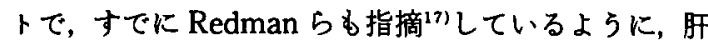
細胞内に多数の VLDL 分泌顆粒がみられたことは, VLDL の細胞内輸送，および分泌過程が障害されたこ とを示したものであろら。また，本実験では，コルヒ 
チン投与ラットで，類洞側の肝細胞質で secondary lysosomeに取り込まれたインスリンの grainが観察 されたが、これは、コルヒチン投与により，インスリ ンの細胞内渝送障害が起こり，その代謝・非泄が漣延 した結果，肝細胞内に蓄積してきたインスリンを分解 するために lysosome に取り込まれたるのと推察され た.

\section{結語}

${ }^{125} \mathrm{I}$ インンスリンをラットの腸間膜静脈より投与し, その肝細胞への取り込み，ならびに肝細胞内輸送動態 を，光顕および電顕オートラジオグラフィーを用いて 観察した。

1）投与したインスリンは, 中心静脈周囲肝細胞に比 し，門脈周囲肝細胞に有意に多く取り込まれた。

2）インスリンは類洞血中より endocytosisにより 肝細胞に取り込まれ, vesicleによって肝細胞内を毛細 胆管へと輸送され，胆汁中へ排泄されると考えられた。 また,一部のインスリンは, RER，核膜に運ばれると考 えられた。

3）コルヒチン投与により microtubules 障害する と、インスリンの取り込みには影響はみられないか， その肝細胞内輸送,および胆汁中への排泄は抑制され, インスリンの肝細胞内輸送には, microtubules が重要 な役割をなしていると考えられた。

稿を終るにあたり，御指導，御校閲を賜りました谷川久一 数授に深詶致します。また，終始御指尊いただいた安倍弘彦 助教授，向坂彰太郎博士に感謝するとともに，御協力下さい ました研究室の皆様に深謝致します。なお，本論文の要旨の 一部は, 第19回日本肝䑏学会西部会(1984年)にて発表した。

$$
\text { 文献 }
$$

1) Renston $R H$, Jones $A L$, Christinansen $W D$, et al: Evidence for a vesicular transport mechanism in hepatocytes for bilialy secretion of immunoglobulin. A Science 208: 1276-1278, 1980

2) Iozzo RV, Kushwaha RS, Wight TN, et al : Cellular and subcellular distribution of ${ }^{125}$. labeled very low density lipoprotein in the liver of normal and estrogen-treated rabbits. Am J Pathol 107: 6-15, 1982

3) Rappaport AM, Borowy ZJ, Louqheed WM, et al: Subdivision of hexagonal liver lobules into a structural and functional unit: Role in hepatic physiology and pathology. Anat Rec 119 :
$11-34,1954$

4）向坂彰太郎：低比重肝細胞と高比重肝細胞の電子 湿鏡的 Morphometric analysis と培碏下にお ける Allyl Alcohol に対する反応性について。 日 消誌 $79: 64-71 ， 1982$

5) Groothuis GMM, Hardonk MJ, Keulemans KPT, et al: Autoradiographic and kinetic demonstration of acinar heterogeneity of taurocholate transport. Am J Physiol 243: G455 $-\mathrm{G} 462,1982$

6) Pastan $I H$, Willingham MC: Journey to the center of cell : Role of the receptosome. Science 214 : 504-509, 1981

7) Renston RH, Maloney DG, Jones $A L$, et al : Bile secretory apparatus: Evidence for a vesicular transport mechanism for proteins in the rat. using horseradish peroxidase and [ $\left.{ }^{125} \mathrm{I}\right]$ insulin. Gastroenterology 78 : 1373-1388, 1980

8) Jones $A L$, Ronston RH, Burwen SJ : Uptake and intracellular disposition of plasma-derived proteins and apoproteins by hepatocytes. In : progress in Liver diseases, Edited by $\mathrm{H}$ Popper, F Schaffner. Vol VII. Grune \& Stratton, New York, 1982, p51-69

9) Goldfine ID, Jones AL, Hradek GT, et al: Electron microscope autoradiographic analysis of [225I] iodoinsulin entry into adult rat hepatocytes in vivo : Evidence for multiple sites of hormone localization. Endocrinology 108 : 1821 $-1828,1981$

10) Bergeron JJM, Sikstrom R, Hand AR, et al: Binding and uptake of ${ }^{125} \mathrm{I}$-insulin into rat liver hepatocytes and endotherium: An in vivo radioautographic study. J Cell Biol $80: 427$ $-443,1979$

11) Carpentier JL, Gorden $P$, Barazzone $P$, et al : Intracellular localization of ${ }^{125} \mathrm{I}$-insulin in hepatocytes from intact rat Liver. proc Natl Acad Sci VSA 76: 2803-2807, 1979

12) Meyts PD, Hanoune J: Plasma membrane receptors and function. In : The Liver : Biology and Pathology, Edited by I Arias, H Popper, D Schachter, et al : Reven Press, New York, 1982, p551-580

13) Kasuga $M$, Zick $Y$, Blith $D L$, et al: Insulin stimulation of phosphorylation of the $\beta$ subnit 
of the insulin receptor. J Biol Chem $257: 9891$ $-9894,1982$

14) Goldfine ID: Interaction of insulin, polypeptide hormones, and growth factors with intracellular membranes. Biochem Biophys Acta $650: 53-67,1981$

15) Sakisaka $S$, Ishii $Y$, Ueda $H$, et al: The mechanism of intracellular transport of horseradish peroxidase and the role of microtubules in the hepatocytes J Clin Electron Microscopy $15: 417-418,1982$

16）向坂彰太郎，谷川久一：種々の物質の肝細胞内渝 送機構と血中ならびに胆汁中動態について，肝缄 25:1196-1197, 1984

17) Redman CM, Banerjee $D$, Howell $K$, et al : Colchicine inhibition of plasma protein release from rat hepatocyte. J Cell Biol 66 : 42-59, 1975

\section{The mechanism of intracellular transport of ${ }^{125}$ I-insulin in the hepatocyte: Light and electron microscopic autoradiographic studies}

\section{Kazuhisa GONDO*}

Light and electron microscopic autoradiographies were used to demonstrate the hepatocellular uptake of insulin and its distribution in hepatocytes.

${ }^{125}$ [-insulin injected into the mesenteric vein of rats was taken up by hepatocytes predominantly in the periportal region of the lobule.

125I-insulin was taken up into hepatocytes by pinocytosis from the sinusoidal blood and packed into coated vesicles.

Then, ${ }^{125}$ I-insulin was translocated by the vesicular transport toward the canalicular pole and excreted into the bile canaliculi.

Some of 125I-insulin grains were distributed on the rough endoplasmic reticulum and nuclear membrane. The inhibition of microtubular function by colchicine had no effect on the hepatocellular uptake of ${ }^{125}$ I-insulin. However, the intracellular transport in hepatocytes of 225 Iinsulin was inhibited by colchicine.

These results suggested that the insulin taken up by hepatocytes predominantly in the periportal region is transported by the vesicular transport to the bile canaliculi, and microtubules may play an important role in the intracellular transport.

* The Second Department of Internal Medicine, Kurume University School of Medicine (Kurume) 